lateral pair of eyes, and of a dark brown colour. Falces small, conical, armed with teeth on the inner surface, and inclined towards the sternum, which is heart-shaped: maxillæ inclined towards the lip, which is semicircular and prominent at the apex : legs moderately long and hairy; the anterior and posterior pairs are the longest and are equal in length, and the third pair is the shortest; each tarsus is terminated by three claws; the two superior ones are curved and pectinated, and the inferior one is inflected near its base. These parts are of a pale brown hue, the falces being the darkest and the sternum having a tinge of green. The four intermediate eyes describe a narrow, oblong trapezoid, whose anterior side is the shortest, and those of each lateral pair are seated obliquely on a small tubercle and are contiguous; the lateral eyes are the largest, and the two anterior ones of the trapezoid are the smallest of the eight. The palpi resemble the legs in colour, with the exception of the radial and digital joints, which have a dark brown tint; the radial is stronger than the cubital joint, and projects two pointed apophyses from its extremity, in front ; the digital joint is oval, convex and hairy externally, concave within, comprising the palpal organs, which are highly developed, prominent, complicated in structure, with a short, curved, black, projecting spine at their extremity, and are of a brown colour tinged with red. Abdomen small, oviform, hairy, convex above, projecting over the base of the cephalothorax ; it is of a yellowish brown colour, with obscure marks of a deeper shade.

A specimen of this minute Walckenaëra, in a state of maturity, was discovered among moss growing at the root of an oak in a wood on the northern slope of Gallt y Rhyg in October 1852.

III.-Description of a new genus of Calanidæ. By John Lubbock, Esq.

[With a Plate.]

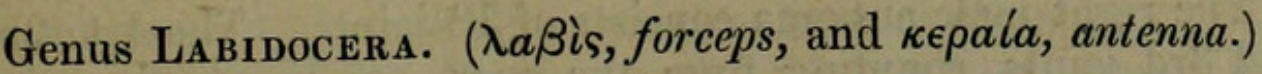

Rostrum furcatum; antenna antica maris dextra geniculans, tumida, articulis quarto et quinto magna serrata lamella instructis. Oculi superiores duo, magni, distantes. Oculi inferiores nulli. Cephalothorax 7 -articulatus. Maxillipedes externi, grandes, setis longis setulosis. Pes posticus maris dexter, crassus, prehensilis.

Rostrum forked; superior right male antenna prehensile, swollen, the ninth and tenth joints furnished each with a large 
serrated plate. Eyes two, large, distant. Cephalothorax 7. jointed. External maxillipeds large, bearing long setose hairs. Right male thoracic leg, of the fifth pair, swollen, prehensile.

I have after much hesitation described this as a new genus, on account of the number and position of the eyes, and of the very remarkable structure of the ninth and tenth joints of the right male antenna.

From Calanus, Dana; Scribella, Dana ; Acartia, Dana ; Euchata, Dana, and Undina, Dana, it differs in having the right male antenna prehensile.

From Calanus, Scribella, Euchata, Undina, Caudace, Dana; Cyclopsina, Dana, and Catopia, Dana, in having two large distant eyes.

From Acartia, in having the right fifth leg in the male prehensile, and two instead of four eyes.

From Pontella, Dana, in having two large distant eyes instead of three.

From Cetochilus, M.-Ed., in having the right fifth leg in the male prehensile.

From Anomalocera, Tem., in having two eyes in both sexes.

And from all these genera in the structure of the superior right male antenna.

Cephalothorax: 7-jointed; the first three large and nearly equal, the next four gradually diminished in size.

Eyes: large, distant, one on each side of the head; alike in both sexes.

Between the two anterior antennæ is a rounded projection analogous to that which in the neighbouring genera contains the inferior eye ; in Labidocera, however, the eye itself is absent, at least Mr. Darwin, who examined the mouth when they were fresh, did not observe it, and had it been coloured like the other two he could not have overlooked it ; and besides, though I could easily dissect out the lenses of the superior eyes, I could not find one here*.

Anterior antenna: female and left male simple, 24-jointed, like those of Pontella, \&c.

The right male antenna consists of 13 joints. The 1st, 2 nd, and 3rd joints, counting from the apex, are simple, long and narrow; the first terminated by a few short hairs, the second and third bearing each a long hair at the apex. The fourth long, narrow, and produced forward into a dentated plate; closely applied to, and rather longer than, the joint itself. The

* The colouring matter of the eyes of Entomostracans must differ chemically from that of the Zoea, Gammari, \&c., for in Mr. Darwin's specimens (which bave been in spirits of wine nearly twenty years) the colour in the former was entirely destroyed, while that of the latter was unaltered. 
fifth short and produced backwards in form of a strong plate, as long as the sixth joint, turned outwards, and knobbed at the end and strongly serrated, which forms with the corresponding plate of the fourth joint a most beautiful prehensile apparatus (Pl. I. fig. 3, $3 a$ open, $3 b$ closed), whose action will be presently described. The sixth joint is as long as the plate of the fifth, narrow at the apex, and gradually increasing in size to the base. The outer margin is straight, the inner rather curved and bearing two pairs of hairs ; the 7th, 8th, and 9th are short and broad, their breadth exceeding their length; the 10th is longer and narrower; the 11th, 12th, and 13th the same length but broader; the 7 th, 8 th, 9th, 10th, 11th, and 12th with a row of hairs externally.

Rising at the exterior basal angle of the ninth joint a strong voluntary muscle passes through the 8 th, 7 th, 6 th, and is inserted into the apex of the fifth joint; the action of which is to draw back the apex of the fifth joint towards the sixth (fig. $3 b$ ), which throws the serrated plate forwards and towards the plate of the tenth joint.

This antenna is coloured and extended in front of the animal, while the right is colourless and doubled down close to the body.

Second pair of antenna (fig. 2) consist of three joints, the apical rather swollen at the end and bearing a tuft of hairs ; the basal supporting a simple appendage not quite so long as the second joint of the other branch, and also terminated by a tuft of hairs.

Mandibles (fig. 4). Strong, six-toothed, the two external teeth the largest, and each terminated by a small spine, the sixth longer than the rest and more like a stout spine; bearing a large palpus, which is provided at its apex with two lobes, nearly equal, and each terminated by a tuft of long, setose hairs.

Internal maxillipeds (fig. 5) consist of a basal joint bearing. two lobes, each with several strong setose hairs; opposite the lobes is another tuft of longer, also setose hairs, between which and the lobes is attached an oval plate, deeply notched at the extremity, and likewise bearing setose hairs at the apex.

Second pair of maxillipeds (fig. 6). A small triangular lobe with a few long setose hairs at the extremity, and a long, simple, six-jointed palpus, also terminated by a tuft of hairs.

External maxillipeds (fig. 7). Large, bearing many long, stout, slightly curved hairs setose internally, and showing traces of being three-jointed. The extremity of the seven external hairs is curiously crenated.

Thoracic legs. The first four pair (fig. 8) consist of a twojointed basal part, where arise a long three-jointed and a shorter 
two-jointed branch, both clothed internally and at the apex with long setose hairs, and the outer branch also bearing several short, stout spines externally, and showing traces of other joints.

Fifth pair of thoracic legs. Female. Small, simple, consisting of a basal joint, bearing two, a large and a smaller, simple slightly curved pointed joints ; the outer and larger one bearing one or two small, short spines (fig. 10).

Male (fig. 9). The right leg in the male is large and prehensile; the first joint somewhat pentagonal, broad; the second sinıple, cylindrical; the third very much swollen at the apex, containing a very powerful muscle, bearing at its external basal angle a large spine, which, with the claw articulated at the corresponding apical angle, forms a very powerful prehensile apparatus. The left simpler, smaller leg (fig. $9 a$ ) is three-jointed and gradually tapers to the apex, where there are two, a longer and a shorter, strong, slightly bent spines. Internally at its apex it bears a tuft of very fine short hairs. Attached to the basal joint is a two-jointed appendage, not so long as the leg itself, and whose second joint is very curiously ringed (the rings however, at least at the base, do not go quite across), and evidently extensible, as in some specimens it was much longer and thinner than in others. In it (fig. $9 b$ ) was a wide vessel containing a brown pulpy substance, but I could not trace it quite to the apex (though as far as the second ring), nor see any opening, which, considering the minuteness of the object, is not perhaps to be wondered at. Mr. Darwin and Dr. Baird* both regard this organ, on account of its structure and position, as the penis, in support of which it may be remarked, that Mr. Darwin observed that this pair of legs was frequently moved and retained irritability longer than any other part of the body, which appears to indicate them as the seat of some important function, which can hardly be any other than that we have assigned to them, more especially as the female organs of generation in other animals are most retentive of irritability. The penis in all Cirrhipeds is also ringed.

Neither Dana nor Milne-Edwards have noticed any organ similar to this in any of the neighbouring genera; so it is probable that in them it is not so much developed.

Abdomen (figs. 1 \& 11) is four-jointed in the male and two. jointed in the female, and, like that of Pontella, \&c., gives off two caudal lamellæ, each provided at the end with a few long plumose hairs.

The anus is, I believe, situated between the lamellæ, as I have traced the intestine thus far, and Mr. Darwin noticed its peristaltic motion in the abdomen.

* Both of whom have very kindly given me the benefit of their advice in drawing up this paper. 


\section{Labidocera Darwinii.}

There being as yet only one species in this family no specific description need be given.

Colour blue-green, sometimes with brown spots. $\frac{1}{10}$ th inch in length.

Hab. Atlantic Ocean, lat. $38^{\circ}$ south, in the open sea off the coast of Patagonia.

I received the specimens from $\mathrm{Mr}$, Darwin, to whom I am indebted for great kindness and advice, and who has kindly permitted me to call it after him.

\section{EXPLANATION OF PLATE I.}

Fig. 1. Labidocera Darwinii. Male.

Fig. 2. Second pair of antennæ.

Fig. 3. Anterior antenna. $3 a$. Prehensile apparatus open. $3 b$. Ditto closed.

Fig. 4. Mandible.

Fig. 5. First pair of maxillipeds.

Fig. 6. Second ditto.

Fig. 7. Third ditto.

Fig. 8. Thoracic leg: 1st, 2nd, 3rd, and 4th pair.

Fig. 9. Posterior thoracic legs. Male. $9 a$. Left leg more magnified to show the penis. $9 \mathrm{~b}$. Apical joint of penis.

Fig. 10. Posterior thoracic legs. Female.

Fig. 11. Abdomen. Female.

IV.-Characters of several Helices from West Australia and the Mauritius; with Notes on some species of Cyclostoma from Borneo. By W. H. Benson, Esq.

1. Helix plectilis, nobis, n. s.

Testa subobtecte perforata, globulosa, albida, opaca, valde rugosa, superne rugis perobliquis elevatis, angulato-flexuosis, irregularibus, subtus versus umbilicum rectis, radiatis, munita; spira elevatiuscula, suturis distinctis, apice obtuso; anfractibus 4 , convexis, ultimo antice deflexo ; apertura circulari, perobliqua, peristomate undique expanso, reflexiusculo, subcontinuo, marginibus approximatis, conniventibus, callo lato junctis, columellari late reflexo, umbilicum plus minusve obtegente.

Diam. major 15, minor 12 , axis 10 mill.

Hab. ad oras sinus "Shark's Bay" dicti Australiæ Occidentalis.

Remarkable for the bold, deeply fretted sculpture of the upper side, extending below the periphery, and then merging into moderate radiating folds. In form it wonderfully resembles $H$. nivosa, Sow., of Porto Santo, but differs in the partly covered umbilicus, the expansion and reflexion of the peristome, the cir- 


\section{$2 \mathrm{BHL}$ Biodiversity Heritage Library}

Lubbock, John. 1853. "III.-Description of a new genus of Calanidæ." The Annals and magazine of natural history; zoology, botany, and geology 11, 25-29. https://doi.org/10.1080/03745485609495753.

View This Item Online: https://www.biodiversitylibrary.org/item/48966

DOI: https://doi.org/10.1080/03745485609495753

Permalink: $\underline{\text { https://www.biodiversitylibrary.org/partpdf/24726 }}$

\section{Holding Institution}

Natural History Museum Library, London

\section{Sponsored by}

Natural History Museum Library, London

\section{Copyright \& Reuse}

Copyright Status: Public domain. The BHL considers that this work is no longer under copyright protection.

This document was created from content at the Biodiversity Heritage Library, the world's largest open access digital library for biodiversity literature and archives. Visit BHL at https://www.biodiversitylibrary.org. 